\title{
Reduction of liver manganese concentration in response to the ingestion of excess zinc: identification using metallomic analyses.
}

\section{$\operatorname{AUTHOR}(\mathrm{S}):$}

Fujimura, Tomoya; Terachi, Tomohiro; Funaba, Masayuki; Matsui, Tohru

\section{CITATION:}

Fujimura, Tomoya ...[et al]. Reduction of liver manganese concentration in response to the ingestion of excess zinc: identification using metallomic analyses.. Metallomics: integrated biometal science 2012, 4(8): 847-850

\section{ISSUE DATE:}

2012-06-13

URL:

http://hdl.handle.net/2433/175392

\section{RIGHT:}

(C) The Royal Society of Chemistry 2012.; この論文は出版社版でありま せん。引用の際には出版社版をご確認じ利用ください。; This is not the published version. Please cite only the published version. 
Reduction of liver manganese concentration in response to the ingestion of excess zinc: identification using metallomic analyses

Tomoya Fujimura, Tomohiro Terachi, Masayuki Funaba* and Tohru Matsui

Division of Applied Biosciences, Kyoto University Graduate School of Agriculture, Kitashirakawa Oiwakecho, Kyoto 606-8502, Japan

Corresponding author: Masayuki Funaba, Ph.D.

Division of Applied Biosciences

Kyoto University Graduate School of Agriculture

Kitashirakawa Oiwakecho, Kyoto 606-8502, Japan

Tel.: +81-75-753-6055

Fax: +81-75-753-6344

E-mail: mfunaba@kais.kyoto-u.ac.jp 


\section{Abstract}

To date, minerals of interest have been analyzed individually to understand mineral dynamics and metabolism. Our recent development of metallomic analyses enabled us to evaluate minerals in an unbiased and global manner. Here, we evaluated effects of the ingestion of excess zinc on the plasma and tissue concentrations of minerals in growing rats. A total of 26 minerals were simultaneously evaluated by the metallomic analyses using an inductively-coupled plasma-mass spectrometry in semi-quantification mode; the concentrations of several minerals exhibited consistent changes in response to the concentration of dietary zinc. The manganese concentrations in plasma and femur were increased, whereas those in the liver and pancreas were decreased with increasing dietary zinc concentrations. Because the interaction between zinc and manganese has not been known, we further focused our analysis on liver manganese. Quantitative analyses also indicated that the hepatic concentration of manganese decreased in response to the ingestion of diets containing excess zinc, a result that was partly explained by the decreased expression of hepatic Zip8, a manganese transporter. The present study reveals a mineral interaction using metallomic analyses and proposes a possible mechanism underlying the novel interaction. 


\section{Introduction}

Many minerals are essential for a variety of biological processes because of the ability of these minerals to serve as enzyme co-factors, oxygen transporters, second messengers to elicit cell responses, and body supports. Therefore, excesses and deficiencies of minerals cause serious metabolic disorders. ${ }^{1,2}$ In addition, inappropriate mineral intake induce secondary disturbances in metabolism of other minerals through agonistic or antagonistic interactions between minerals. ${ }^{1,3}$ Furthermore, there are interactions between mineral metabolism and the metabolism of macronutrients such as sugars, fats and proteins. ${ }^{4-6}$ However, because minerals of interest have been analyzed individually to date, the information is limited. Recently, we developed the "metallomic analyses" using a semi-quantitative procedure based on inductively-coupled plasma-mass spectrometry (ICP-MS). ${ }^{7}$ This method enables the unbiased and comprehensive evaluation of mineral dynamics through global measurement of the tissue mineral concentrations. The present study uses this method to explore the effects of excess levels of dietary zinc $(\mathrm{Zn})$ on the mineral concentrations in tissues and plasma in growing rats.

\section{Materials and methods}

\section{Samples}

The samples collected in the previous study ${ }^{8}$ were used; a total of 28 -wk-old male specific-pathogen-free Sprague-Dawley rats were used. They were housed individually in stainless-steel cages under constant conditions $\left(24^{\circ} \mathrm{C}, 50 \%\right.$ humidity $)$ with a fixed light-dark cycle (lights on from 0500 to 1900) and were randomly assigned to receive diets containing differing $\mathrm{Zn}$ concentrations, i.e., 24, 1016, 2008 and $3000 \mathrm{mg} \mathrm{Zn/kg} \mathrm{(n}$ =7). Weaning piglets are frequently given a high $\mathrm{Zn}$ diet, because the diets containing this level of $\mathrm{Zn}$ improved body weight gain (3000 mg Zn/kg diet). ${ }^{9-11}$ Therefore, diets with $\mathrm{Zn}$ levels as high as $3000 \mathrm{mg} \mathrm{Zn} / \mathrm{kg}$ diet were included and given to growing rats. ${ }^{8}$ Ingredients and composition of diets were previously described. ${ }^{8}$ Briefly, egg-white was used as a protein source, because this is a part of the study examining responses to dietary $\mathrm{Zn}$ status, i.e., excess intake as well as deficiency. D-biotin was added to the diet due to the high avidin content of egg-white to prevent biotin deficiency. Zn was added as $\mathrm{ZnO}$ at the expense of glucose. The measured concentrations of dietary manganese (Mn) were 7.55, 7.80, 7.47 and $8.47 \mathrm{mg} / \mathrm{kg}$ in the diets containing 24, 1016, 2008 and $3000 \mathrm{mg} \mathrm{Zn/kg}$, respectively. All rats showed no signs of Zn toxicity- namely, they did not vomit or show any gastrointestinal dysfunction throughout the study, although two 
rats fed a diet with $3000 \mathrm{mg} \mathrm{Zn/kg}$ excreted soft stools for the last $3 \mathrm{~d}$ of the experimental period. No significant differences between the dietary groups were detected on body weight and daily feed intake. ${ }^{8}$ These results are consistent with the previous results that a diet with $2500 \mathrm{mg} \mathrm{Zn} / \mathrm{kg}$ did not interfere with growth, reproduction and normal function of rats through three generations. ${ }^{12}$ After $10 \mathrm{~d}$ of feeding the experimental diet, tissues and plasma were collected. The experiments were approved by the Kyoto University Animal Experiment Committee (20-19).

\section{Metallomic analyses and quantification of $\mathrm{Mn}$}

The metallomic analysis was performed for screening to detect mineral interactions. Plasma (1 ml), liver (ca. $0.5 \mathrm{~g}$ ), pancreas (ca. $0.5 \mathrm{~g}$ ), kidney (one kidney) and femur (one femur) from each rat were wet-ashed with trace-element grade nitric acid and hydrogen peroxide, and the minerals in the sample were dissolved in $2 \%$ nitric acid to $50 \mathrm{ml}$. The tissue samples were accurately weighed. The femur samples were further diluted 10-fold with $2 \%$ nitric acid, whereas the other samples were diluted 5-fold. To obtain the representative tissue concentration of the minerals, samples from each group were pooled. Comprehensive analyses of the minerals were performed using an ICP-MS (Elan6000, Perkin Elmer, Norwalk, CT) in semi-quantification mode (TotalQuant III). ${ }^{7}$ A total of 26 minerals was evaluated by this metallomic analysis. The results were visualized by a two-dimensional graphical representation of the mineral contents in red and green using Treeview. ${ }^{13}$ As in transcriptomic analyses, the graphical representation makes the analyses of metallomic data much easier. ${ }^{14}$

The Mn concentrations in the liver and the diets were individually quantified by ICP-MS in quantification mode. The analytical accuracy for the Mn quantitation (mass number: 55) was confirmed by analysis of a certified reference material derived from bovine liver (standard reference material 1577b, National Institute of Standards and Technology, Gaithersburg, MD, USA); intrassay CV and interassay CV were $0.5 \%$ and $3.1 \%$, respectively, and recovery was $98.6 \%$.

\section{RNA isolation and qRT-PCR}

RNA isolation from the liver and qRT-PCR were performed as described previously. ${ }^{8}$ The following primers were used: 5'-ttttggtgggcaacaacttt-3' and 5'-gcatgtcgttcatctctgga-3' for Zip8 (NCBI accession number: NM_001011952) and 5'-ttcctcagtgtctcactgattaa-3' and 5'-ggaaaagtgcgttagagagc-3' for Zip14 (NM_001107275). Hprtl was used as a reference gene as described previously. ${ }^{8}$ The 
relative level of each gene transcripts was expressed as a ratio with respect to Hprt1 mRNA, and the level in rats fed the basal diet were set to 1 .

\section{Statistical analyses}

Data are expressed as the least square mean \pm SEM. All analyses were performed with SAS $^{15}$ using the supercomputer of ACCMS, Kyoto University. The effects of dietary Zn on the Mn concentration and gene expression were analyzed with the GLM procedure. When the effect of diet was significant, the differences among the groups were examined by Tukey's multiple comparison test. Differences were considered significant at $P<0.05$.

\section{Results and discussion}

Metallomic analyses indicated that feeding diets containing various $\mathrm{Zn}$ contents for $10 \mathrm{~d}$ expectedly resulted in changes in plasma $\mathrm{Zn}$ concentrations that paralleled the dietary $\mathrm{Zn}$ concentrations, except for rats fed the diet containing $3000 \mathrm{mg} \mathrm{Zn/kg} \mathrm{(Fig.} \mathrm{1).} \mathrm{This}$ result is consistent with the quantified concentrations of the plasma $\mathrm{Zn}$ as shown in the previous report $^{8}$; the $\mathrm{Zn}$ concentrations in plasma linearly increased with increasing concentrations of dietary $\mathrm{Zn}$ up to $2008 \mathrm{mg} \mathrm{Zn} / \mathrm{kg}$, after which the plasma concentrations plateaued.

Several minerals other than $\mathrm{Zn}$ exhibited consistent changes in their concentrations in response to changing dietary $\mathrm{Zn}$ concentrations (Fig. 1). Among them, we paid attention to $\mathrm{Mn}$ concentrations; $\mathrm{Mn}$ concentrations in the plasma and femur were increased, whereas those in the liver and pancreas were decreased with increasing dietary $\mathrm{Zn}$ concentrations.

Because $\mathrm{Mn}$ is an essential mineral in animals ${ }^{2,16,17}$ and because the interaction between $\mathrm{Zn}$ and Mn has not been known, ${ }^{3,17}$ we further focused our analysis on the liver Mn concentration. We performed quantitative analyses of the liver Mn concentration; as consistent with the semi-quantitative analysis, it was lower in rats fed diets containing more than $1016 \mathrm{mg} / \mathrm{kg} \mathrm{Zn}$ than in rats fed the diet containing $24 \mathrm{mg} / \mathrm{kg} \mathrm{Zn} \mathrm{(Fig.} \mathrm{2A).}$ Gajula et al. ${ }^{18}$ reported that liver concentrations of Mn were comparable among chicks fed diets containing 40, 80 and $120 \mathrm{mg} \mathrm{Zn/kg}$ for $27 \mathrm{~d}$. Peixoto et al. ${ }^{19}$ also reported that the subcutaneous administration of $\mathrm{ZnCl}_{2}$ at a dose of $27 \mathrm{mg} / \mathrm{kg}$ body weight/d for $5 \mathrm{~d}$ did not affect the Mn concentrations in liver and kidney of 13-d-old rats. Differences 
between the species, in the dietary $\mathrm{Zn}$ concentrations or in the duration may be responsible for the discrepant results. Additionally, the diet used by Gajula et al. ${ }^{18}$ was mainly $(<90 \%)$ composed of corn and soybeans, which contain phytic acid, a compound that inhibits $\mathrm{Zn}$ absorption. ${ }^{20}$ Thus, it is possible that the presence of phytic acid affected the interactions between $\mathrm{Zn}$ and $\mathrm{Mn}$.

The present results suggested that the plasma and tissue concentrations of $\mathrm{Mn}$ are differentially affected by the levels of ingested $\mathrm{Zn}$ in a tissue-dependent manner. This result reflects the altered body distribution of $\mathrm{Mn}$ in response to the ingestion of excess $\mathrm{Zn}$, suggesting that the expression and activity of Mn transporters are modulated in response to dietary $\mathrm{Zn}$ levels to regulate Mn delivery. Zip8 is a transporter responsible for Mn uptake. ${ }^{21}$ The transcript level in the liver was lower in rats fed the diets containing $1016 \mathrm{mg} \mathrm{Zn/kg} \mathrm{and} 2008 \mathrm{mg} \mathrm{Zn/kg}$ than in those fed the diet containing 24 $\mathrm{mg} \mathrm{Zn} / \mathrm{kg}$, although the expression level in rats fed the diet containing $3000 \mathrm{mg} \mathrm{Zn} / \mathrm{kg}$ was not significantly different from that in control rats (Fig. 2B). By contrast, the expression of Zip14, which is another Zn transporter ${ }^{22}$ and is also involved in Mn uptake, $^{23}$ was unchanged, irrespective of dietary $\mathrm{Zn}$ levels (Fig. 2C). The down-regulation of Zip8 but not Zipl4 in rats fed the diet containing 1016-2008 mg $\mathrm{Zn} / \mathrm{kg}$ partly explains the decrease in the hepatic accumulation of $\mathrm{Mn}$. The molecular bases how excess $\mathrm{Zn}$ intake affects Zip8 expression are not clear yet. It should also be noted that factors other than the hepatic expression of Zip8 and Zip14 are involved in the decreased Mn concentrations in the liver of rats fed the diet containing $3000 \mathrm{mg}$ $\mathrm{Zn} / \mathrm{kg}$. In view of the transcriptional and post-transcriptional regulation of the activities of the Zip family members, ${ }^{24}$ the lower Mn concentration may be the result of additional modifications. Alternatively, it is also possible that $\mathrm{Mn}$ export from the liver is accelerated in rats fed the diet containing $3000 \mathrm{mg} \mathrm{Zn/kg}$. Either way, further studies are needed for full clarification on modulation of Mn transporters.

The present study identified a novel interaction between minerals. There was a decrease in the hepatic concentration of $\mathrm{Mn}$ in response to the ingestion of diets containing excess $\mathrm{Zn}$. The nutritional and pathological significance of the modulated $\mathrm{Mn}$ concentration should be clarified in future; because $\mathrm{Mn}$ is a co-factor of various enzymes including oxidoreductases, transferases, hydrolases, lyases, isomerases and ligases, the changes in $\mathrm{Mn}$ content in the tissue may affect the activities of some enzymes. Thompson et al. ${ }^{25}$ showed that hepatic Mn concentration was reduced from $2.88 \mu \mathrm{g} / \mathrm{g}$ to $1.22 \mu \mathrm{g} / \mathrm{g}$ by ingestion of $\mathrm{Mn}$ deficient diet in rats, and suggested the 
increase in oxidative stress in the liver of rats fed the Mn deficient diet. In view of the similar extent of the reduction on hepatic Mn concentrations (Fig. 2A), it is possible that the excess $\mathrm{Zn}$ induces hepatic Mn deficiency and oxidative stress. In the present study, regulation of the expression of $\mathrm{Mn}$ transporters was further investigated based on knowledge obtained from the metallomic analyses. In conclusion, we demonstrate that the metallomic analysis using ICP-MS in semi-quantification mode is a powerful tool with which to comprehensively and deeply explore mineral dynamics in animals.

\section{Acknowledgments}

The authors thank Drs. Y. Itokawa and M. Kimura for giving us a chance to use ICP-MS.

\section{References}

1 E.J. Underwood, N.F. Suttle, in The Mineral Nutrition of Livestock, 3rd Edn., CAB International, Oxon, 1999, p. 47.

2 L.R. McDowell, in Minerals in Animal and Human Nutrition, 2nd Edn., Elsevier, Amsterdam, 2003, p. 1.

3 V.I. Georgievskii, in Mineral Nutrition of Animals, eds. V.I. Georgievskii, B.N. Annenkov and V.I. Samokhin, Butterworth, London, 1982, p. 11.

4 S.M. Kaup, A.R. Behling, L. Choquette and J.L. Greger, J. Nutr., 1990, 120, 266.

5 R. Ivaturi and C. Kies, Plant Foods Hum. Nutr., 1992, 42, 143.

6 J.J. Cao and F.H. Nielsen, Curr. Opin. Clin. Nutr. Metab. Care, 2010, 13, 698.

7 K.H. Kim, N. Ishizaki, E. Iguchi, M. Funaba and T. Matsui, Biol. Trace Elem. Res., in press.

8 T. Fujimura, T. Matsui and M. Funaba, Br. J. Nutr., in press.

9 I. Mavromichalis, C.M. Peter, T.M. Parr, D. Ganessunker and D.H. Baker, J. Anim. Sci., 2000, 78, 2896.

10 G.M. Hill, D.C. Mahan, S.D. Carter, G.L. Cromwell, R.C. Ewan, R.L. Harrold, A.J. Lewis, P.S. Miller, G.C. Shurson and T.L. Veum, J. Anim. Sci., 2001, 79, 934.

11 X. Li, J. Yin, D. Li, X. Chen, J. Zang and X. Zhou, J. Nutr., 2006, 136, 1786.

12 V.G. Heller and A.D. Burke, J. Biol. Chem., 1927, 74, 85.

13 M.B. Eisen, P.T. Spellman, P.O. Brown and D. Botstein, Proc. Natl. Acad. Sci. USA, 1998, 95, 14863. 
14 F.M. Selaru, T. Zou, Y. Xu, V. Shustova, J. Yin, Y. Mori, F. Sato, S. Wang, A. Olaru, D. Shibata, B.D. Greenwald, M.J. Krasna, J.M. Abraham and S.J. Meltzer, Oncogene, 2002, 21, 475.

15 SAS Institute, SAS User's Guide: Statistics, Ver. 9.2, SAS Institute, Cary, 2001.

16 E.J. Underwood, N.F. Suttle, in The Mineral Nutrition of Livestock, 3rd Edn., CAB International, Oxon, 1999, p. 397.

17 L.R. McDowell, in Minerals in Animal and Human Nutrition, 2nd Edn., Elsevier, Amsterdam, 2003, p. 335.

18 S.S. Gajula, V.K. Chelasani, A.K. Panda, V.L. Mantena and R.R. Savaram, Biol. Trace Elem. Res., 2011, 139, 177.

19 N.C. Peixoto, L.C. Rocha, D.P. Moraes, M.J. Bebianno, V.L. Dressler, E.M. Flores and M.E. Pereira, Chemosphere, 2008, 72, 1327.

20 B. Lönnerdal, J. Nutr., 2000, 130, 1378S.

21 L. He, K. Girijashanker, T.P. Dalton, J. Reed, H. Li, M. Soleimani and D.W. Nebert, Mol. Pharmacol., 2006, 70, 171.

22 J.P. Liuzzi, F. Aydemir, H. Nam, M.D. Knutson and R.J. Cousins, Proc. Natl. Acad. Sci. USA, 2006, 103, 13612.

23 K. Girijashanker, L. He, M. Soleimani, J.M. Reed, H. Li, Z. Liu, B. Wang, T.P. Dalton and D.W. Nebert, Mol. Pharmacol., 2008, 73, 1413.

24 L.A. Gaither and D.J. Eide, Biometals, 2001, 14, 251.

25 K.H. Thompson, D.V. Godin and M. Lee, Biol. Trace Elem. Res., 1992, 35, 213. 
Figure legends

Fig. 1. Metallomic analyses of plasma and tissues of rats fed diets containing various levels of $\mathrm{Zn}$

The plasma and tissues of rats fed diets containing 24, 1016, 2008 or $3000 \mathrm{mg} \mathrm{Zn/kg}$ were analyzed. The plasma and tissues concentrations of the rats fed the basal diet (24 $\mathrm{mg} \mathrm{Zn} / \mathrm{kg}$ ) were set at 1 , and concentrations relative to the concentration in rats fed the basal diet are shown in red (higher concentration) or green (lower concentration). Gray indicates concentrations below the detection limit.

Fig. 2. Quantitative measurement of Mn, and gene expression of Zip8 and Zip14 in the livers of rats fed diets containing various levels of $\mathrm{Zn}$

The liver concentrations of Mn (A) and the expression levels of hepatic Zip8 (B) and Zip14 (C) were investigated in rats fed diets containing 24, 1016, 2008 or $3000 \mathrm{mg}$ $\mathrm{Zn} / \mathrm{kg}$. The gene transcript levels were expressed as ratios relative to Hprtl with the level in rats fed the basal diet set to 1 . Values are the means $+\operatorname{SEM}(n=7)$. a, b: Mean values with different letters were significantly different $(P<0.05)$. 
Dietary Zn level:

\section{Plasma}

$\mathrm{Li}$

$\mathrm{M}$
$\mathrm{P}$
$\mathrm{K}$
$\mathrm{Ti}$
$\mathrm{V}$

$\mathrm{Cr}$

$\mathrm{Mn}$

Co

$\mathrm{Cu}$

$\mathrm{Zn}$

Se

$\mathrm{Rb}$

$\mathrm{Nb}$

Mo

$\mathrm{Rh}$

$\mathrm{Ag}$

Sn

Cs

La

$\mathrm{Ce}$

$\mathrm{Pr}$

$\mathrm{Hf}$

W

TI

$\mathrm{Pb}$

\section{Liver}
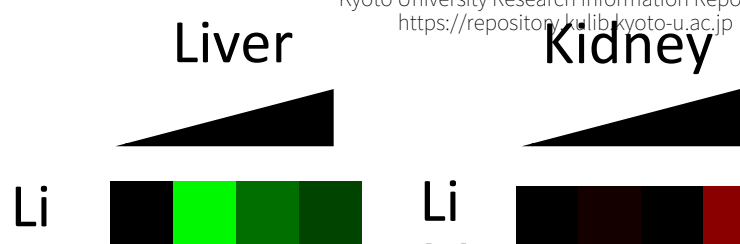

$\mathrm{Mg}$

$\mathrm{P}$

$\mathrm{K}$

$\mathrm{Ti}$

$\mathrm{V}$

$\mathrm{Cr}$

$\mathrm{Mn}$

Co

$\mathrm{Cu}$

$\mathrm{Zn}$

$\mathrm{Se}$

$\mathrm{Rb}$

$\mathrm{Nb}$

Mo

$\mathrm{Rh}$

$\mathrm{Ag}$

Sn

Cs

La

$\mathrm{Ce}$

$\mathrm{Pr}$

$\mathrm{Hf}$

W

$\mathrm{TI}$

$\mathrm{Pb}$

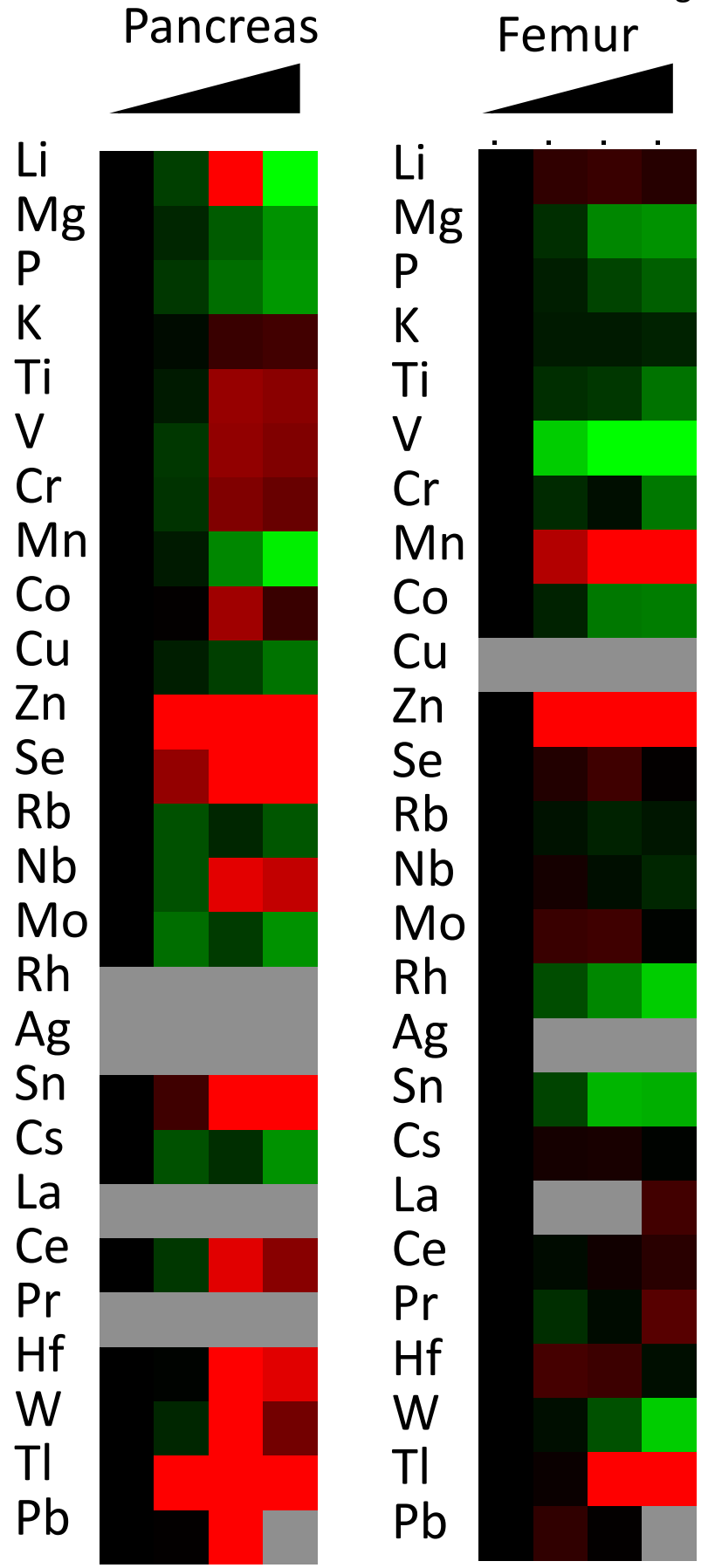




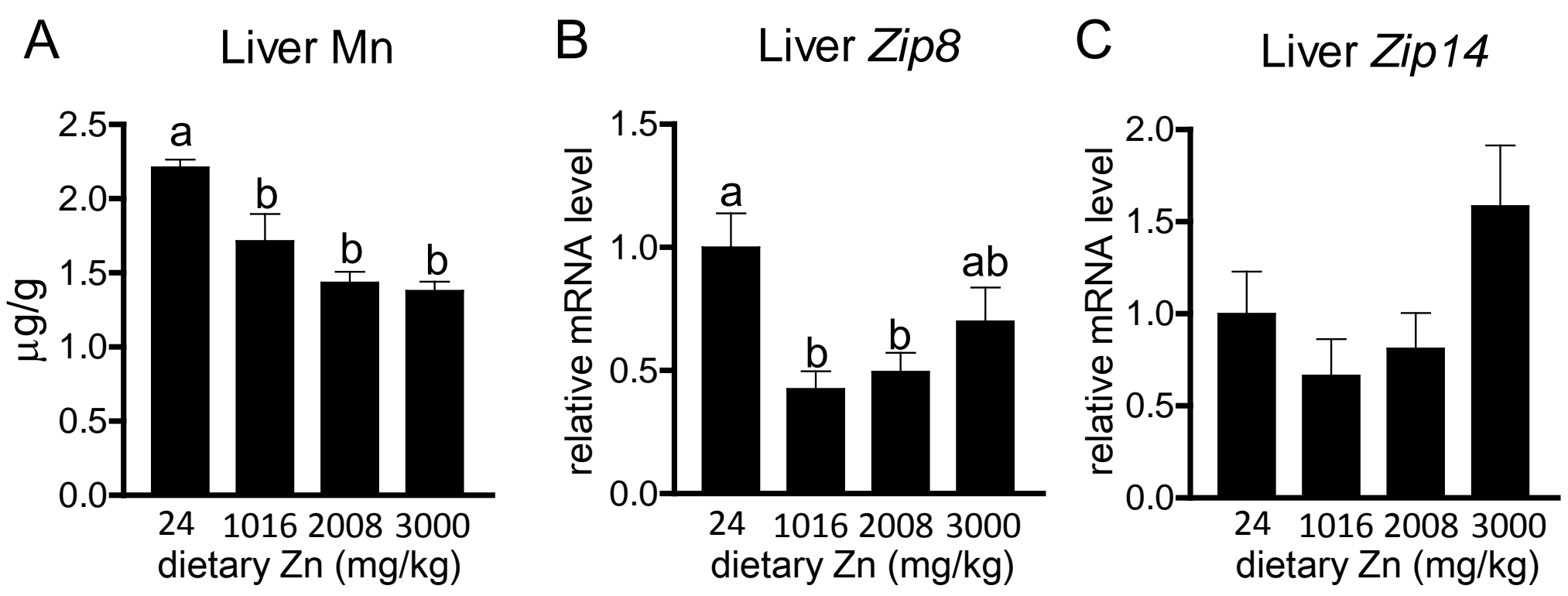

